\title{
Influence of Soil and Manure Management Practices on Surface Runoff Phosphorus and Nitrogen Loss in a Corn Silage Production System: A Paired Watershed Approach
}

\author{
Jessica F. Sherman ${ }^{1}\left[\right.$, Eric O. Young ${ }^{1, *}$ (D) , William E. Jokela ${ }^{1}$, Michael D. Casler ${ }^{2}$, Wayne K. Coblentz ${ }^{1}$ \\ and Jason Cavadini ${ }^{3}$ \\ 1 USDA-ARS, Institute for Environmentally Integrated Dairy Management, 2615 Yellowstone Dr., \\ Marshfield, WI 54449, USA; jessica.sherman@usda.gov (J.F.S.); jokela@wisc.edu (W.E.J.); \\ wayne.coblentz@usda.gov (W.K.C.) \\ 2 USDA-ARS, Dairy Forage Research Center, 1925 Linden Dr., Madison, WI 53706, USA; \\ michael.casler@usda.gov \\ 3 Marshfield Agricultural Research Station, University of Wisconsin, M605 Drake Ave., \\ Stratford, WI 54484, USA; jason.cavadini@wisc.edu \\ * Correspondence: eric.young@usda.gov
}

check for updates

Citation: Sherman, J.F.; Young, E.O.; Jokela, W.E.; Casler, M.D.; Coblentz, W.K.; Cavadini, J. Influence of Soil and Manure Management Practices on Surface Runoff Phosphorus and Nitrogen Loss in a Corn Silage Production System: A Paired Watershed Approach. Soil Syst. 2021, 5,1. https://doi.org/10.3390/ soilsystems 5010001

Received: 14 November 2020 Accepted: 24 December 2020 Published: 29 December 2020

Publisher's Note: MDPI stays neutral with regard to jurisdictional claims in published maps and institutional affiliations.

Copyright: () 2020 by the authors. Licensee MDPI, Basel, Switzerland. This article is an open access article distributed under the terms and conditions of the Creative Commons Attribution (CC BY) license (https: / / creativecommons.org/ licenses/by/4.0/).

\begin{abstract}
Best management practices (BMPs) can mitigate erosion and nutrient runoff. We evaluated runoff losses for silage corn management systems using paired watershed fields in central Wisconsin. A two-year calibration period of fall-applied liquid dairy manure incorporated with chisel plow tillage (FMT) was followed by a three and a half-year treatment period. During the treatment period FMT was continued on one field, and three different systems on the others: (a) fall-applied manure and chisel tillage plus a vegetative buffer strip (BFMT); (b) a fall rye cover crop with spring manure application and chisel tillage (RSMT), both BMPs; a common system (c) fall manure application with spring chisel tillage (FMST). Year-round runoff monitoring included flow, suspended sediment (SS), total phosphorus (TP), dissolved reactive phosphorus (DRP), ammonium $\left(\mathrm{NH}_{4}{ }^{+}-\mathrm{N}\right)$, nitrate, and total nitrogen (TN). Results showed BFMT reduced runoff SS, TP, and TN concentration and load compared to FMT. The RSMT system reduced concentrations of SS, TP, and TN, but not load because of increased runoff. The FMST practice increased TP, DRP, and $\mathrm{NH}_{4}{ }^{+}-\mathrm{N}$ loads by 39, 376, and 197\%, respectively. While BMPs showed mitigation potential for SS, TN, and TP, none controlled DRP, suggesting additional practices may be needed in manured corn silage fields with high runoff potential.
\end{abstract}

Keywords: best management practices; corn silage; erosion; nutrient management; liquid manure; surface runoff; water quality

\section{Introduction}

Corn silage is an important crop to dairy producers in the US and globally. A lack of crop residue after silage harvest increases erosion potential and phosphorus $(\mathrm{P})$ and nitrogen $(\mathrm{N})$ transport to surface waters compared to less erosive crops [1-7]. The US dairy industry faces increasing pressure from regulatory agencies and the public to improve on-farm nutrient use efficiency while decreasing environmental impacts [8]. While dairy manure application on silage fields provides needed nutrients and is a source of organic matter for soil quality, it also contributes to runoff $\mathrm{P}$ and $\mathrm{N}$ losses and greenhouse gas emissions [8].

Nutrient management practices such as manure application methods, tillage practices, cover crops, and grass buffers can reduce erosion and $\mathrm{P}$ transport in corn production systems [1-3,5,9-17], however, it is important to recognize that they can also have differential effects on sediment and $P$ transport. For example, cover crops and reduced tillage can decrease erosion and particulate P loss but increase bioavailable P loss in the form of 
dissolved reactive $\mathrm{P}$ (DRP) transport in surface runoff [18-20]. With long-term reduced and/or no-tillage, DRP can be increased relative to conventional tillage from a combination of lower erosion, nutrient stratification, and/or dissolved nutrient release from crop residues [21-24]. Snowmelt runoff in cold climates often accounts for a substantial fraction of total annual runoff and $\mathrm{N}$ and $\mathrm{P}$ loss. Several studies conducted in cold climates report a dominance of DRP in snowmelt runoff compared to particulate $\mathrm{P}$, which tends to be higher with more erosive rainfall events compared to snowmelt $[19,25,26]$. Establishing a winter rye cover crop after corn silage harvest in the fall can help mitigate dissolved and particulate-bound nutrients in surface runoff, including ammonium- $\mathrm{N}\left(\mathrm{NH}_{4}{ }^{+}-\mathrm{N}\right)$ and nitrate-N $\left(\mathrm{NO}_{3}-\mathrm{N}\right)[5,11,27,28]$. Grass buffer strips are another commonly recommended $\mathrm{BMP}$ to reduce erosion and edge-of-field nutrient loss in agricultural systems $[15,29]$. Mayer et al. [30] compared data from 88 studies evaluating vegetative buffer $\mathrm{N}$ removal effectiveness and concluded adequate vegetation was a critical factor for mitigating erosion and enhancing $\mathrm{N}$ attenuation. While plant buffer species did not affect $\mathrm{N}$ removal, buffers $>50 \mathrm{~m}$ removed $\mathrm{N}$ more consistently than 0 to $25 \mathrm{~m}$ wide strips.

Research indicates that individual and combinations of best practices can mitigate erosion and surface runoff nutrient loss potential. Much of this is from field plots, however, which largely ignores the dynamic nature and complex hydrology of larger fields/watersheds [31-33]. Evaluating the effectiveness of practices at the landscape and watershed scales is also challenging due to the heterogeneity of runoff processes [34-36]. Paired watershed designs account for inherent physiographic differences between watersheds and can help to isolate management effects on runoff water quality $[9,32,37,38]$. The objective of this study was to use a paired-watershed approach to quantify the effectiveness of targeted BMPs to mitigate surface runoff nutrient transport from corn silage fields in central Wisconsin (WI) with high runoff potential. Specifically, the following management systems were compared to the typical practice of fall manure application with chisel tillage incorporation (FMT) (see Table S1 for abbreviation guide): (i) fall-applied manure and chisel tillage with the inclusion of a grass-legume buffer strip along the lower field edge (BFMT); (ii) a fall rye cover crop with spring manure application and chisel tillage (RSMT); (iii) fall manure application with spring chisel tillage (FMST).

\section{Materials and Methods}

\subsection{Research Site}

This study was conducted at the University of Wisconsin/USDA-ARS Marshfield Agricultural Research Station near Stratford, WI. The fields are mapped as somewhat poorly drained Withee silt loam (fine-loamy, mixed, superactive, frigid Aquic Glossudalfs; $1-3 \%$ slope). These soils have a dense, compacted B-horizon at approximately $50 \mathrm{~cm}$ resulting in high runoff potential. The 30-year average annual temperature and precipitation at the site are $6.9^{\circ} \mathrm{C}$ and $831 \mathrm{~mm}$, respectively. The site is comprised of four forage crop production fields separated by earthen berms directing runoff to individual flumes, with each field functioning as a small watershed. Each field is approximately 1.6 ha and are referred to individually as M1, M2, M3, and M4. The average field slope is approximately $2 \%$ for M1, M2, and M4. The average slope for field M3 is $0.25 \%$ for the lower third of the field area and $3 \%$ for the upper $2 / 3$ of the field. The lower area of M3 is more imperfectly drained with visible standing water after heavy rainfall and snowmelt events. More details on site establishment and calibration period (2006-2008) results are presented in Jokela and Casler [39].

\subsection{Field Treatments and Agronomic Considerations}

During the calibration period (2006-2008), all fields were managed identically with fall liquid dairy manure application (at a rate to meet $80 \%$ of annual corn $\mathrm{N}$ need) and chisel plow tillage to a depth of $15 \mathrm{~cm}$ ( $2.7 \mathrm{~m}$ wide seven-shank plow Landoll Farm Equipment, Brillion, WI, USA) the same day. Field cultivation to a depth of $7.5 \mathrm{~cm}(6.2 \mathrm{~m}$ wide John Deere, Moline, IL, USA) was performed in the spring before planting corn. 
The same management was continued on the designated control field (M1) during the treatment period, but management was changed on the others. Field M4 (BFMT) was treated identically to M1 but with the addition of a mixed grass-legume buffer strip ( $9.8 \mathrm{~m}$ wide) along the lower side of the field above the drainageway. The buffer strip was planted on 3 October 2008 using a no-till drill (John Deere 1590, Moline, IL, USA) with $112 \mathrm{~kg} \mathrm{ha}^{-1}$ winter rye (Secale cereale L.), $2.2 \mathrm{~kg} \mathrm{ha}^{-1}$ alsike clover (Trifolium hybridum L.), $9.0 \mathrm{~kg} \mathrm{ha}^{-1}$ tall fescue (Festuca arundinaceum), and $3.4 \mathrm{~kg} \mathrm{ha}^{-1}$ smooth bromegrass (Bromus inermis L.). While the vegetative buffer was implemented as a conservation practice, it can also provide an economic return as harvestable hay forage crop for dairy animals and removes soil $\mathrm{N}$ and $\mathrm{P}$. In our study the buffer vegetation was harvested approximately twice per year with field-scale equipment, but yield and nutrient data are incomplete. In $\mathrm{M} 2$, a winter rye cover crop was planted in early Oct after the silage corn harvest at $112 \mathrm{~kg} \mathrm{ha}^{-1}$ with a no-till drill (John Deere 1590, Moline, IL, USA) and manure application and chisel tillage was delayed until spring (RSMT). On field M3, liquid dairy manure was broadcast on the surface in the fall (without incorporation) and chisel tilled the following spring (FMST). While not considered a BMP because of the lack of manure incorporation, it is still a relatively common practice, so we chose to include it to assess potential effects on surface runoff water quality.

Liquid dairy manure was sampled at each application and analyzed for N, P, potassium $(\mathrm{K}), \mathrm{NH}_{4}{ }^{+}-\mathrm{N}$, and dry matter content by the University of WI Soil and Forage Lab [40] (Table 1). Manure application rates averaged $45,880 \mathrm{~L} \mathrm{ha}^{-1}$ and ranged from $3.2 \%$ to $18 \%$ dry matter content. Nutrient application rates are presented in Table 1 . Average total $\mathrm{N}$ and $\mathrm{P}$ application rates from manure were approximately 155 and $24 \mathrm{~kg} \mathrm{ha}^{-1}$ year $^{-1}$, respectively. This $\mathrm{N}$ application met approximately $60 \%$ of crop needs (based on $\mathrm{N}$ availability of $50 \%$ in the first year and $10 \%$ in the second) slightly less than during calibration due to lower manure N contents in 2010 and 2011 than expected. Each year, corn was planted on all fields on the same day. Corn (Zea Mays L.) (2905RB; 89-day RM; YGCB RR, in 2009 and 2010; RK212GT; 81-day RM; RR, in 2011) was planted in May or late April at 87,500 seeds $\mathrm{ha}^{-1}$ with $112 \mathrm{~kg} \mathrm{ha}^{-1}$ of 9-11-30-6S-1Zn starter fertilizer applied as a band (50 $\mathrm{mm}$ to the side of the seed row and $50 \mathrm{~mm}$ deep) via the planter. Additional fertilizer $\mathrm{N}$ was applied in June or July as needed (Table 1) based on a pre-sidedress nitrate soil test [41]. Corn was harvested for silage on the same day for all fields between mid-Sept and early Oct (Table 1). Yields were estimated by hand-harvesting above-ground corn biomass samples (all but the bottom $25 \mathrm{~cm}$ of stalk) from nine randomly selected, $3 \mathrm{~m}$ row-length sub-plots from each field when whole-plant DM content had reached approximately $350 \mathrm{~g} \mathrm{~kg}^{-1}$. Subsamples were taken and a composite plot sample was dried at $55^{\circ} \mathrm{C}$, ground to pass $1 \mathrm{~mm}$, and analyzed for total N (Elementar Variomax CN analyzer, Ronkonkoma, NY, USA) and P content after nitric acid digestion by ICP-OES (University of WI Soil and Forage Lab) to estimate corn $\mathrm{N}$ and $\mathrm{P}$ removal. Soil samples were collected: nine $2.5-\mathrm{cm}$ diameter, $20-\mathrm{cm}$ deep samples were taken in each watershed with a hand sampler, every fall throughout the treatment phase, and in the spring of 2012. Plant-available P was extracted using the Bray 1 solution ( $0.03 \mathrm{~N}$ ammonium fluoride $+0.025 \mathrm{~N}$ hydrochloric acid; [42]). Phosphorus in extracts was determined colorimetrically (ammonium molybdate solution) using standard techniques (abbreviated as B1P). 
Table 1. Field activities and manure composition during the 2008-2011 treatment period.

\begin{tabular}{|c|c|c|c|c|c|c|}
\hline & Manure & & & & & \\
\hline Event & Nutrient $^{+}$ & 2008 & 2009 & 2010 & 2011 & 2012 \\
\hline Fall Rye & & & & & & \\
\hline $\begin{array}{c}\text { Planting } \\
(\text { M2/RSMT } \ddagger)\end{array}$ & & 3 October & 8 October & 7 October & 4 October & \\
\hline $\begin{array}{c}\text { Fall Manure } \\
\text { Application } \\
\text { (M1/FMT; }\end{array}$ & & 3 November & 10 November & 4 November & 9 November & \\
\hline M3/FMST; & \multicolumn{6}{|c|}{$\mathrm{kg} \mathrm{ha}^{-1}$} \\
\hline & $\mathrm{N}$ & 200 & 164 & 59 & 130 & \\
\hline & $\mathrm{P}$ & 28 & 29 & 10 & 24 & \\
\hline & K & 86 & 152 & 81 & 143 & \\
\hline & $\mathrm{NH}_{4}-\mathrm{N}$ & 96 & 85 & 35 & 65 & \\
\hline & DM & 8715 & 6303 & 1085 & 5570 & \\
\hline $\begin{array}{l}\text { Spring Manure } \\
\text { Application }\end{array}$ & & & 8 May & 27 April & 27 May & 1 May \\
\hline (M2/RSMT) & & & \multicolumn{4}{|c|}{$\mathrm{kg} \mathrm{ha}^{-1}$} \\
\hline & $\mathrm{N}$ & & 204 & 157 & 147 & 136 \\
\hline & $\mathrm{P}$ & & 25 & 27 & 26 & 22 \\
\hline & K & & 114 & 148 & 134 & 19 \\
\hline & $\mathrm{NH}_{4}-\mathrm{N}$ & & 94 & 67 & 70 & 64 \\
\hline & $\mathrm{DM}$ & & 9718 & 10531 & 5350 & 3992 \\
\hline $\begin{array}{l}\text { Corn Planting } \\
\text { (all watersheds) }\end{array}$ & & & 11 May & 28 April & 31 May & \\
\hline $\begin{array}{c}\text { Sidedress N (kg } \\
\left.\mathrm{ha}^{-1}\right)\end{array}$ & & & 39 & 71 & $42 ; 92$ †‡ & \\
\hline Corn Silage & & & & & & \\
\hline $\begin{array}{l}\text { Harvest (all } \\
\text { watersheds) }\end{array}$ & & & 30 September & 14 September & 5 October & \\
\hline
\end{tabular}

\footnotetext{
${ }^{\dagger} \mathrm{N}=$ nitrogen, $\mathrm{P}=$ phosphorus, $\mathrm{K}=$ potassium, $\mathrm{NH}_{4}-\mathrm{N}=$ ammonium nitrogen; ${ }^{\ddagger} \mathrm{RSMT}$ = fall rye (cover crop) with spring applied manure and chisel tillage; FMST = fall applied manure with spring tillage; BFMT = fall applied manure/chisel tillage with grass buffer; ${ }^{\dagger \ddagger} 42 \mathrm{~kg}$ $\mathrm{ha}^{-1}$ on M1 and M4; $92 \mathrm{~kg} \mathrm{ha}^{-1}$ on M2 and M3.
}

\subsection{Hydrology and Runoff Measurements}

Details on runoff instrumentation and monitoring are found in Jokela and Casler [39] and are briefly described here. Runoff was sampled and monitored at gauging stations located at the low elevation point of each field. Original flume design and monitoring procedures were based on those of the US Geological Survey with slight modifications [43]. A $60 \mathrm{~cm}$ fiberglass H-flume (Tracom, Inc., Alpharetta, GA, USA) was attached to pressuretreated plywood wingwalls (driven to approximately $60 \mathrm{~cm}$ deep and extending approximately $3 \mathrm{~m}$ on each side). In November 2007, $1.8 \mathrm{~m}$ long channels were installed between the wingwall and the flume to provide more uniform flow entering the flume and a greater distance for deposition of sediment ahead of the flume [44]. Plywood wingwalls were replaced with steel sheet pilings placed $1.2 \mathrm{~m}$ deep at M2 on 11 May 2012 and M3 on 24 Mar 2010 because of failure due to frost heaving. Flumes were mounted with threaded rods for leveling as needed. Shallow earthen berms directed surface runoff to each flume. During late fall through early spring, plywood enclosures were attached to the approach channel/flume and a quartz heater was used as needed to prevent freezing of sample lines. Instrumentation was housed inside a $1.8 \times 2.1 \times 2.0 \mathrm{~m}^{3}$ high shed (Niagara model, Yardmate Series, Royal Outdoor Products, Inc., Middleburg Heights, OH, USA) equipped with AC power for data loggers, sampling equipment, heaters, and heat tape with battery backup power.

Runoff volume was determined by the measuring stage in the $\mathrm{H}$-flumes with an air bubbler/pressure transducer flow meter (ISCO Model 4230, Teledyne Isco, Inc., Lincoln, 
NE, USA). A bubbler PVC tube ( $3.175 \mathrm{~mm}$ i.d) was attached to the floor of the flume $40 \mathrm{~mm}$ back from the outlet. Staff gages were also installed in the H-flumes to allow simultaneous comparison of the stage with that from the flow meter. Time-based runoff samples were collected at intervals based on estimated event runoff quantity by an automated 24-bottle (1 L) refrigerated sampler (ISCO 6712SR, Teledyne Isco, Inc., Lincoln, NE, USA). A sampling tube ( $9.3 \mathrm{~mm}$ i.d.) was attached to the flume floor near the flume outlet and extended approximately $2 \mathrm{~m}$ to the automated sampler inside the enclosure (protected from freezing by heat tape and foam insulation). A CR10X datalogger (Campbell Scientific, Inc., Logan, UT, USA) was used to read and store data and control the runoff sampling collection scheme. A weather station (Campbell Scientific, Inc., Logan, UT, USA) was located $1000 \mathrm{~m}$ from the site and measured precipitation (tipping bucket), air temperature, humidity, wind, and solar irradiance. Real-time, two-way radio telemetry allowed remote communication with each station and the weather station. A Campbell scientific software program (PC208W) was used for real-time communication to modify sampling intervals as needed.

\subsection{Nutrient and Runoff Water Quality Measures}

Samples from individual autosampler bottles were combined into a flow weighted composite for each runoff event. Samples were analyzed for suspended sediment (SS; gravimetric method 3977-97B) [45], total P (TP; block digestion, method 4500 P F; [46]), and total Kjeldhal N (TKN; block digester automated colorimetric, $4500 \mathrm{NH}_{3} \mathrm{G}$; [46]), a filtered $(0.45 \mu \mathrm{m})$ subsample was analyzed for DRP (automated colorimetric method 4500 P F; [46]), nitrate + nitrite-N; abbreviated as $\mathrm{NO}_{3}-\mathrm{N}$ (automated Cd reduction; $4500 \mathrm{NO}_{3} \mathrm{~F} 5$; [46]), and $\mathrm{NH}_{4}{ }^{+}-\mathrm{N}$ (automated phenolate, $4500 \mathrm{NH}_{3} \mathrm{G} ;$ [46]). Values for $\mathrm{TKN}$ and $\mathrm{NO}_{3}-\mathrm{N}$ were added to provide an estimate of total $\mathrm{N}(\mathrm{TN})$ since $\mathrm{NO}_{3}-\mathrm{N}$ is not measured in the TKN procedure.

\subsection{Statistical Analysis}

Paired watershed analysis involves edge-of-field runoff water quality monitoring of two or more fields similar in soil characteristics with hydrologic isolation to enable fields to function as individual small watersheds. Watersheds are treated identically during the calibration/baseline period to account for runoff variation among watersheds, and event-based runoff data is collected. During the treatment phase, the control watershed continues with same treatment while treatment designated watersheds receive different management treatments. Treatment and calibration regression equations are then tested statistically for differences to determine treatment effects. The direction and magnitude of the effect are determined by comparing values predicted by calibration regression to those observed during the treatment period.

In the present study, the treatment period runoff water quality data are presented in relation to previously reported calibration period results [39]. The number of paired runoff events for statistical analysis ranged from $n=34$ to 39 during the calibration period and $n=55$ to 61 events during the treatment period. All dependent runoff water quality variables measured (and model residuals) were non-normally distributed. While log transformation is commonly done for non-normality and heteroscedasticity (e.g., [10,19]), log transformations rarely normalized variables and did not adequately resolve variance heterogeneity for this study. A generalized linear mixed modeling approach (log-link function) was also conducted [47] with several distribution types, but heteroscedasticity remained an issue. Given these limitations, permutation tests $[48,49]$ were conducted (rather than analysis of covariance/regression) to test two hypotheses for each dependent variable: (1) calibration period mean equals treatment period mean and (2) calibration period slope equals treatment period slope. A total of 1000 permutations were generated by randomly reassigning calibration and treatment data to the two time periods followed by one-way analysis of variance (Hypothesis 1 ) or randomly sorting $\mathrm{x}$-axis values followed by estimation of permuted slopes (Hypothesis 2). Hypothesis tests for means and slopes were conducted as two-tailed tests with $p$-values set at $0.25,0.10,0.05$, and 0.01 to define significance levels. Predicted constituent concentrations/loads were based on 
calibration regression equations of Jokela and Casler [39]. The relative impact of BMPs on water quality was expressed as the percent difference between predicted (i.e., from calibration phase equations) and measured values for the treatment. Corn silage yield and soil nutrient data were analyzed by mixed models analysis of variance [50].

\section{Results and Discussion}

\subsection{Weather and Corn Silage Yield}

Precipitation during the treatment period (2008-2011) was slightly greater $(10 \%)$ compared to the calibration period (2006-2008) and more pronounced in the growing season ( $36 \%$ greater than the calibration period; Table 2). Treatment phase growing season rainfall was similar to the 30 -year average, whereas the calibration period was $32 \%$ drier. During the calibration period, measured runoff averaged $14 \%$ of total precipitation. For the treatment phase, the mean runoff fraction was considerably higher ( $26 \%$ of precipitation), most likely due to the overall wetter conditions increasing runoff potential in these somewhat poorly drained soils. Average temperatures for calibration and treatment periods were similar to the 30-year mean.

Corn yield averaged across fields was $16.2 \mathrm{Mg} \mathrm{ha}^{-1}$ for the treatment period and in the range of expected yields for central Wisconsin. There were some yield differences among fields with notably lower yield for FMST, which could have been related to greater $\mathrm{NH}_{3}$ volatilization due to the lack of fall incorporation. However, the lower third of field M3 becomes more imperfectly drained as the main field slope levels out and runoff water collects. It is therefore likely that greater $\mathrm{N}$ loss from not incorporating manure and the more imperfectly drained section of M3 contributed to the lower average yield. Averaged across the treatment period, yields ranged from 15 to $17 \mathrm{Mg} \mathrm{ha}^{-1} ; \mathrm{N}$ and $\mathrm{P}$ uptake ranged from 177 to 192 and 21.9 to $25.4 \mathrm{~kg} \mathrm{ha}^{-1}$, respectively. Yield, N, and $\mathrm{P}$ removal differences among fields were also noted for the calibration phase [39]. For the calibration period average yield (17.3 $\left.\mathrm{Mg} \mathrm{ha}^{-1}\right), \mathrm{N}$ and $\mathrm{P}$ removal (197 and $34.7 \mathrm{~kg} \mathrm{ha}^{-1}$, respectively) were highest for field M2 (RSMT for the present study), while average yields for the other fields were similar (16 to $16.6 \mathrm{Mg} \mathrm{ha}^{-1}$ ). 
Table 2. Monthly average temperatures $\left({ }^{\circ} \mathrm{C}\right)$ and precipitation totals $(\mathrm{cm})$ at the Marshfield Agricultural Research Station, Stratford, Wisconsin.

\begin{tabular}{|c|c|c|c|c|c|c|c|c|c|c|c|c|c|c|c|c|}
\hline Month & 2006 & 2007 & 2008 & 2009 & 2010 & 2011 & 2012 & $\begin{array}{c}\text { Average } \\
1981-2010\end{array}$ & 2006 & 2007 & 2008 & 2009 & 2010 & 2011 & 2012 & $\begin{array}{c}\text { Average } \\
\text { 1981-2010 }\end{array}$ \\
\hline & & \multicolumn{7}{|c|}{${ }^{\circ} \mathrm{C}$} & \multicolumn{8}{|c|}{$\mathrm{cm}$} \\
\hline January & & -6.8 & -10.7 & -14.4 & -7.9 & -11.1 & -6.9 & -9.1 & & 2.3 & 2.9 & 1.1 & 2.2 & 1.9 & 3.0 & 2.29 \\
\hline March & & 1.0 & -4.8 & -1.3 & 3.6 & -2.5 & 7.3 & -0.6 & & 4.2 & 1.4 & 3.2 & 1.7 & 4.8 & 3.3 & 4.45 \\
\hline April & & 6.1 & 5.6 & 6.7 & 10.6 & 5.2 & 7.4 & 7.2 & & 2.7 & $\begin{array}{l}1.7 \\
10.7\end{array}$ & 7.3 & 2.0 & 9.0 & 5.8 & 7.11 \\
\hline May & & 14.9 & 11.5 & 13.7 & 14.6 & 12.7 & & 13.7 & & 10.3 & 8.4 & 9.4 & 5.8 & 8.1 & & 9.32 \\
\hline June & & 19.4 & 17.9 & 18.2 & 18.6 & 18.4 & & 18.9 & & 8.8 & 9.2 & 6.0 & 13.2 & 10.5 & & 11.3 \\
\hline August & & 20.2 & 19.3 & 18.9 & 21.8 & 20.8 & & 20.1 & & 11.0 & 4.6 & 16.6 & 8.8 & 6.9 & & 10.9 \\
\hline September & 13.4 & 15.9 & 15.8 & 16.8 & 14.0 & 14.1 & & 15.4 & 2.2 & 10.3 & 3.8 & 1.0 & 19.5 & 9.2 & & 10.0 \\
\hline October & 5.6 & 11.6 & 8.3 & 5.4 & 10.4 & 10.1 & & 8.6 & 4.7 & 10.7 & 3.2 & 12.8 & 5.6 & 5.9 & & 6.63 \\
\hline November & 2.2 & 0.1 & 0.9 & 4.6 & -9.2 & 2.2 & & 0.8 & 2.2 & 0 & 3.5 & 1.0 & 2.6 & 2.2 & & 5.64 \\
\hline December & -3.6 & -9.1 & -11.3 & -7.5 & -16.8 & -4.4 & & -6.8 & 4.8 & 7.6 & 5.7 & 5.4 & 0 & 3.4 & & 3.18 \\
\hline $\begin{array}{c}\text { Average } \\
\text { Temperature or Total } \\
\text { Precipitation }\end{array}$ & & 6.9 & 5.1 & 6.1 & 6.4 & 6.7 & & 6.9 & 13.9 & 78.3 & 67 & 66.9 & 87.2 & 84.2 & 12.5 & 83.1 \\
\hline
\end{tabular}




\subsection{Runoff Water Quantity}

Cumulative runoff over the calibration and treatment period ranged from 660 to $980 \mathrm{~mm}$ among the four fields (Figure 1). In the two treatments with spring chisel tillage (RSMT and FMST), runoff increased by 131 and 34\%, respectively, compared to the falltilled control (FMT), whereas runoff for BFMT was similar to the control (FMT), both of which were fall chisel plowed (Table 3). These results are consistent with those of Stock et al. [14], who reported that chisel tillage significantly reduced runoff and nutrient loading in surface runoff from silt loam soils in southern WI. They attributed the lower runoff to greater surface roughness and increased water storage/infiltration compared to no-tillage. The lower increase in runoff for FMST may be due to physical protection of soil structure, essentially a mulching effect aiding infiltration [51,52]. While several studies show cover crops can contribute to lower surface runoff from greater evapotranspiration and soil structural effects [53-55], delaying tillage for RSMT resulted in more runoff in our study. As stated, the decreased surface roughness from delayed plowing likely contributed to increased runoff. However, while delaying tillage until spring could help reduce erosion potential during the non-growing season when runoff risk is elevated, any such effect would probably be minimal with the limited crop residue remaining after silage harvest. Furthermore, any potential beneficial effect of the rye cover crop on runoff in our study was minimized because of its limited fall growth (seeded in October). Percentage cover of rye and other live plant material was 68, 29, and 32 in November 2008, 2010, and 2011, respectively, (2009 data missing), and rye biomass was 500, 338, and $399 \mathrm{~kg} \mathrm{ha}^{-1}$ in late Apr or early May 2010, 2011, and 2012, respectively, before manure application, tillage, and corn planting.
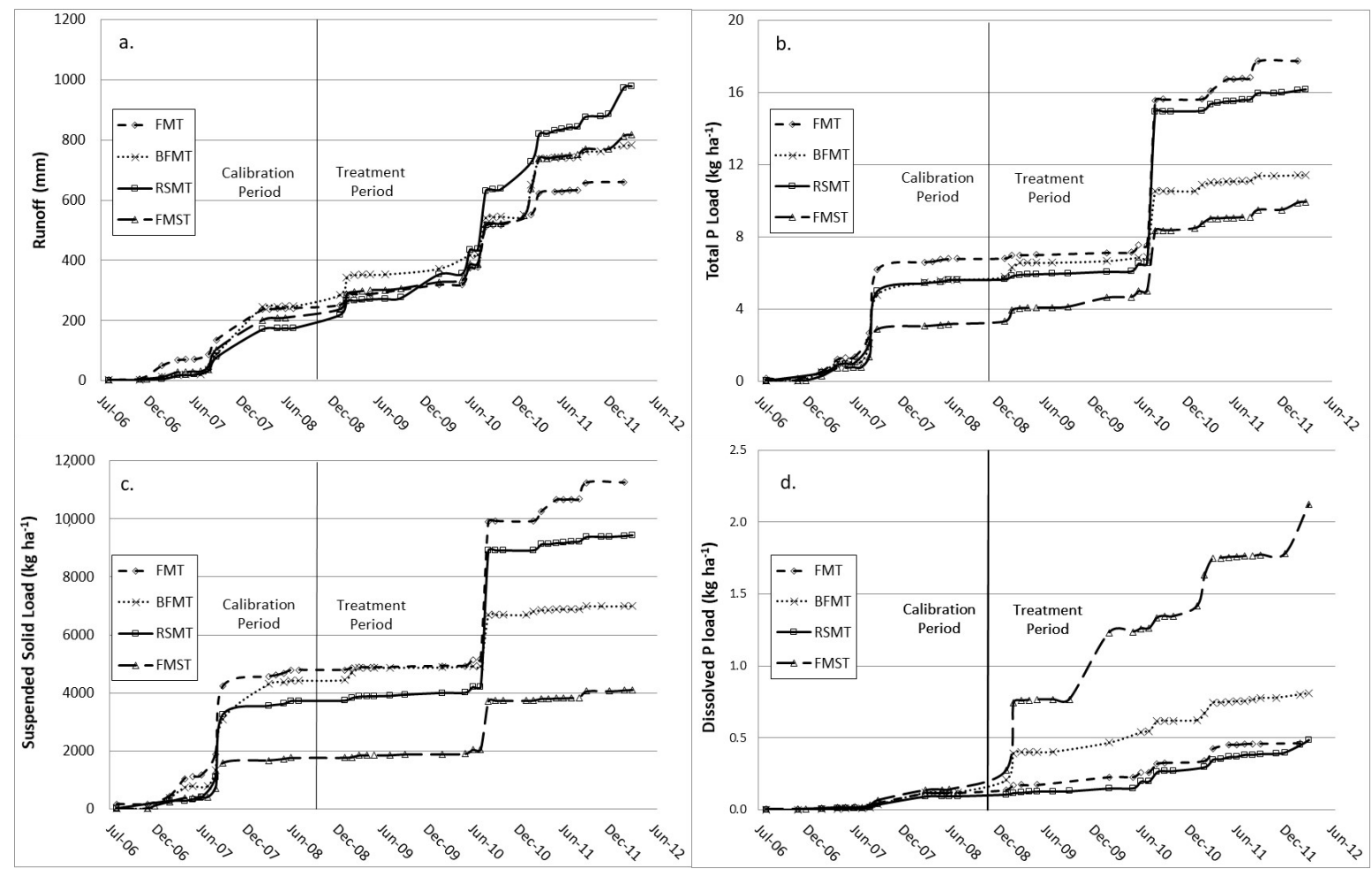

Figure 1. (a) Cumulative runoff (mm), (b) total P load $\left(\mathrm{kg} \mathrm{ha}^{-1}\right)$, (c) suspended sediment load ( $\left.\mathrm{kg} \mathrm{ha}^{-1}\right)$, and (d) dissolved P load ( $\mathrm{mg} \mathrm{kg}^{-1}$ ) over the calibration (2006-2008) and treatment periods (2008-2012) for each watershed; FMT = fall applied manure with chisel tillage, RSMT = fall rye (cover crop) with spring-applied manure and chisel tillage; FMST = fall applied manure with spring tillage; BFMT = fall applied manure/chisel tillage with grass buffer. 


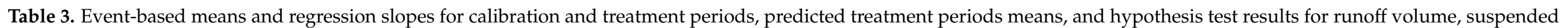
sediment, and nutrient concentrations.

\begin{tabular}{|c|c|c|c|c|c|c|c|c|c|}
\hline Measure & Treatment ${ }^{\dagger}$ & $\begin{array}{l}\text { Calibration } \\
\text { Period Mean }\end{array}$ & $\begin{array}{c}\text { Treatment } \\
\text { Period Mean }\end{array}$ & $\begin{array}{c}\text { Predicted } \\
\text { Treatment } \\
\text { Mean }\end{array}$ & Change $\ddagger$ & Mean $p$-Value ${ }^{\dagger \ddagger}$ & $\begin{array}{c}\text { Calibration } \\
\text { Period } \\
\text { Slope }\end{array}$ & $\begin{array}{c}\text { Treatment } \\
\text { Period Slope }\end{array}$ & Slope $p$-Value \\
\hline & & & $\mathrm{mm}$ & & $\%$ & & & & \\
\hline \multirow[t]{4}{*}{ Mean Surface Runoff } & FMT & 4.5 & 5.0 & & & & & & \\
\hline & BFMT & 5.5 & 6.3 & 6.44 & -2 & NS & 1.32 & 0.91 & + \\
\hline & RSMT & 3.99 & 8.9 & 3.86 & 131 & $*$ & 0.92 & 1.41 & + \\
\hline & FMST & 4.67 & 7.0 & 5.19 & 34 & $\#$ & 0.88 & 0.82 & NS \\
\hline \multirow[t]{4}{*}{ Suspended Sediment } & FMT & 3560 & 953 & & & & & & \\
\hline & BFMT & 2375 & 405 & 828 & -48 & $* *$ & 0.68 & 0.28 & + \\
\hline & RSMT & 2975 & 390 & 766 & -44 & $* *$ & 0.87 & 0.39 & $\#$ \\
\hline & FMST & 1210 & 316 & 431 & -26 & $* *$ & 0.29 & 0.27 & NS \\
\hline \multirow[t]{4}{*}{ Total P } & FMT & 3.87 & 1.48 & & & & & & \\
\hline & BFMT & 3.33 & 0.93 & 1.62 & -39 & $* *$ & 0.87 & 0.30 & * \\
\hline & RSMT & 3.56 & 0.89 & 1.44 & -40 & $* *$ & 0.85 & 0.43 & \# \\
\hline & FMST & 1.67 & 1.18 & 0.69 & 46 & + & 0.46 & 0.20 & + \\
\hline \multirow{3}{*}{ Dissolved Reactive P } & BFMT & 0.05 & 0.17 & 0.08 & 88 & $* *$ & 0.61 & 0.33 & NS \\
\hline & RSMT & 0.05 & 0.09 & 0.08 & -30 & NS & 0.71 & 0.48 & NS \\
\hline & FMST & 0.06 & 0.54 & 0.09 & 312 & $* *$ & 0.57 & 1.15 & NS \\
\hline \multirow[t]{4}{*}{ Total N } & FMT & 23.8 & 10.3 & & & & & & \\
\hline & BFMT & 17.7 & 7.00 & 9.89 & -27 & $* *$ & 0.73 & 0.58 & NS \\
\hline & RSMT & 23.0 & 6.22 & 14.0 & -54 & $* *$ & 0.60 & 0.24 & $*$ \\
\hline & FMST & 12.1 & 7.30 & 8.57 & -23 & $* *$ & 0.28 & 0.23 & NS \\
\hline
\end{tabular}


Table 3. Cont.

\begin{tabular}{|c|c|c|c|c|c|c|c|c|c|}
\hline Measure & Treatment $^{+}$ & $\begin{array}{l}\text { Calibration } \\
\text { Period Mean }\end{array}$ & $\begin{array}{c}\text { Treatment } \\
\text { Period Mean }\end{array}$ & $\begin{array}{c}\text { Predicted } \\
\text { Treatment } \\
\text { Mean }\end{array}$ & Change $\ddagger$ & Mean $p$-Value ${ }^{\dagger \ddagger}$ & $\begin{array}{c}\text { Calibration } \\
\text { Period } \\
\text { Slope }\end{array}$ & $\begin{array}{c}\text { Treatment } \\
\text { Period Slope }\end{array}$ & Slope $p$-Value \\
\hline \multirow[t]{3}{*}{ Nitrate-N } & FMT & 9.9 & 4.40 & & & & & & \\
\hline & RSMT & 10.4 & 2.34 & 4.99 & -48 & $* *$ & 0.86 & 0.07 & $* *$ \\
\hline & FMST & 5.61 & 2.43 & 4.58 & -55 & $* *$ & 0.25 & 0.13 & NS \\
\hline \multirow[t]{4}{*}{ Ammonium-N } & FMT & 1.03 & 0.71 & & & & & & \\
\hline & BFMT & 0.85 & 0.79 & 0.73 & 8 & NS & 0.84 & 0.46 & + \\
\hline & RSMT & 0.82 & 0.40 & 0.54 & -24 & $* *$ & 0.73 & 0.13 & $*$ \\
\hline & FMST & 0.58 & 1.42 & 0.45 & 184 & $* *$ & 0.57 & 0.73 & NS \\
\hline
\end{tabular}

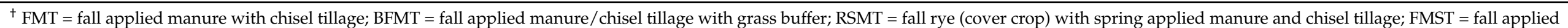

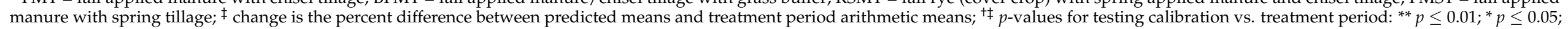
$+p \leq 0.10 ; \# p \leq 0.25, \mathrm{NS} \geq 0.25$. 


\subsection{Runoff Water Quality}

Similar to other studies [22,36,56,57], we found significant relationships between runoff volume and SS, TP, and TN loads (calibration and treatment periods combined). A stronger relationship between TN load and runoff $\left(R^{2}=0.75\right)$ may reflect greater mobility compared to SS and TP $\left(R^{2}=0.26 ; 0.50\right.$, respectively); a large portion $(20$ to $>50 \%)$ of TN load was $\mathrm{NO}_{3}-\mathrm{N}$ further supporting this hypothesis (Table 4). Event runoff TP and TN loads were closely associated with SS loads $\left(R^{2}=0.83 ; 0.74\right.$, respectively), indicating sediment was an important transporter of $\mathrm{P}$ and $\mathrm{N}$ in runoff. Jokela and Casler [39] also reported a strong relationship between runoff SS and TP loads $\left(R^{2}=0.82\right)$, with the exception of two high flow events in early spring 2007 with very high SS.

The influence of management systems on P transport and overall runoff water quality during the treatment period differed. Establishment of a vegetative buffer along with fall manure and tillage (BFMT) significantly decreased $\mathrm{SS}, \mathrm{TP}, \mathrm{TN}$, and $\mathrm{NO}_{3}-\mathrm{N}$ concentrations (Table 3). Loads of SS, TP, TN, $\mathrm{NO}_{3}-\mathrm{N}$ and $\mathrm{NH}_{4}{ }^{+}-\mathrm{N}$ were reduced by $55,28,34,41$, and $22 \%$, respectively (Table 4 ), however, mean DRP concentration and load increased by 88 and 15\%, respectively, compared to predicted means (Tables 3 and 4). In addition to using means to compare treatment effects, regression slopes (treatments vs. control watersheds) for calibration and treatment periods were also compared for constituent loads and concentrations (Tables 3 and 4). As an example, effects of BFMT on runoff and TP load were based on slope comparisons, as illustrated in Figure 2. Plots of the deviation between predicted and observed values for SS and TP load show minimal effects until well into the treatment period (September 2010; Figure 3), perhaps related to time for development of buffer vegetation. While vegetated buffers are generally effective at mitigating surface runoff sediment and particulate P, DRP removal efficiency is generally lower and in some cases positive [58-60]. Reports of episodic DRP release from biomass after freeze-thaw events, presumably due to cell lysis and runoff mobilization [20,21,61-63], may have also contributed to elevated DRP loads for BFMT.

The combination of a post-harvest rye cover crop and delay of manure application/chisel tillage until spring (RSMT) significantly decreased SS, TP, TN, $\mathrm{NO}_{3}-\mathrm{N}$, and $\mathrm{NH}_{4}{ }^{+}-\mathrm{N}$ concentrations by 24 to $54 \%$ (Table 3 ), suggesting potential benefit. However, because of the increased runoff volume, discussed above, there were no decreases in runoff load of any of these parameters. The limited rye growth because of late planting, noted earlier, likely contributed to this. The lack of load reduction of DRP, $\mathrm{NO}_{3}-\mathrm{N}$, and $\mathrm{NH}_{4}{ }^{+}-\mathrm{N}$ is not unexpected because a rye cover crop is considered more effective at reducing erosion and sediment-bound nutrient loss as compared to dissolved nutrients. Unfortunately, some confounding results may have occurred because manure applied in the spring (RSMT) had a 10 to $22 \%$ greater nutrient content than that applied in fall treatments, most pronounced in fall 2010/spring 2011 when differences in $\mathrm{N}, \mathrm{P}$, and $\mathrm{NH}_{4}{ }^{+}-\mathrm{N}$ applied were two-fold or more (Table 1).

The practice of fall-applied manure with spring chisel tillage (FMST) is not considered a BMP, however, it is a fairly common practice for central WI dairy farms and, therefore, the evaluation was deemed important. Not unexpectedly, there were large concentration increases $\left(46,312\right.$, and $184 \%$ increases for TP, DRP, and $\mathrm{NH}_{4}{ }^{+}-\mathrm{N}$, respectively) and large loading increases for DRP and $\mathrm{NH}_{4}{ }^{+}-\mathrm{N}$ (376 and 197\%); TP load also showed a numerical increase of 39\%, but was NS (Tables 3 and 4; Figure 3). Previous studies have also demonstrated the importance of manure incorporation or injection to mitigate runoff $\mathrm{N}$ and $\mathrm{P}$ in corn and hay forage systems $[51,52,64,65]$. There was a significant decrease in $\mathrm{SS}, \mathrm{TN}$, and $\mathrm{NO}_{3}-\mathrm{N}$ concentration, presumably due to the protective soil mulching effect described above regarding runoff effects, but there were no load decreases, except for $\mathrm{NO}_{3}-\mathrm{N}$, because of the increase in runoff. 


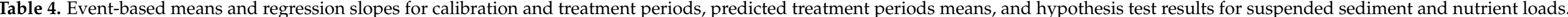

\begin{tabular}{|c|c|c|c|c|c|c|c|c|c|}
\hline Measure & Treatment $^{+}$ & $\begin{array}{l}\text { Calibration } \\
\text { Period Mean }\end{array}$ & $\begin{array}{l}\text { Treatment } \\
\text { Period Mean }\end{array}$ & $\begin{array}{c}\text { Predicted } \\
\text { Treatment } \\
\text { Mean }\end{array}$ & Change $\ddagger$ & Mean $p$-Value ${ }^{\dagger \ddagger}$ & $\begin{array}{l}\text { Calibration } \\
\text { Period Slope }\end{array}$ & $\begin{array}{c}\text { Treatment } \\
\text { Period Slope }\end{array}$ & Slope $p$-Value \\
\hline & & & $\mathrm{kg} \mathrm{ha}^{-1}$ & & $\%$ & & & & \\
\hline \multirow[t]{4}{*}{ Suspended Sediment } & FMT & 146 & 111 & & & & & & \\
\hline & BFMT & 107 & 43.7 & 96.4 & -55 & $*$ & 0.35 & 0.39 & NS \\
\hline & RSMT & 113 & 60 & 54.5 & 10 & NS & 0.72 & 0.95 & + \\
\hline & FMST & 52.8 & 38.5 & 41.6 & -8 & NS & 0.34 & 0.33 & NS \\
\hline \multirow{3}{*}{ Total P } & BFMT & 0.13 & 0.09 & 0.12 & -28 & NS & 0.72 & 0.49 & + \\
\hline & RSMT & 0.13 & 0.11 & 0.09 & 20 & NS & 0.85 & 1.01 & NS \\
\hline & FMST & 0.07 & 0.09 & 0.07 & 39 & NS & 0.44 & 0.41 & NS \\
\hline \multirow[t]{4}{*}{ Dissolved Reactive P } & FMT & 0.002 & 0.006 & & & & & & \\
\hline & BFMT & 0.003 & 0.008 & 0.007 & 15 & $* *$ & 1.06 & 0.29 & $* *$ \\
\hline & RSMT & 0.002 & 0.004 & 0.004 & 3 & + & 0.85 & 0.28 & $* *$ \\
\hline & FMST & 0.003 & 0.030 & 0.006 & 376 & $* *$ & 0.91 & 2.54 & NS \\
\hline \multirow[t]{2}{*}{ Total N } & FMT & 1.12 & 0.77 & & & & & & \\
\hline & FMST & 0.55 & 0.45 & 0.43 & 5 & NS & 0.36 & 0.33 & NS \\
\hline \multirow[t]{4}{*}{ Nitrate-N } & FMT & 0.51 & 0.21 & & & & & & \\
\hline & BFMT & 0.50 & 0.15 & 0.25 & -41 & $* *$ & 0.86 & 0.45 & $\#$ \\
\hline & RSMT & 0.48 & 0.18 & 0.16 & 13 & + & 0.88 & 0.30 & + \\
\hline & FMST & 0.29 & 0.09 & 0.17 & -46 & $* *$ & 0.36 & 0.10 & $\#$ \\
\hline \multirow[t]{4}{*}{ Ammonium-N } & FMT & 0.07 & 0.05 & & & & & & \\
\hline & BFMT & 0.09 & 0.05 & 0.06 & -22 & $\#$ & 1.39 & 0.15 & $*$ \\
\hline & RSMT & 0.05 & 0.03 & 0.03 & 25 & NS & 0.86 & 0.14 & + \\
\hline & FMST & 0.04 & 0.08 & 0.03 & 197 & $*$ & 0.41 & 0.13 & $\#$ \\
\hline
\end{tabular}

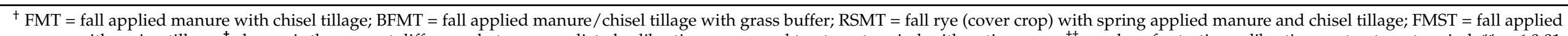

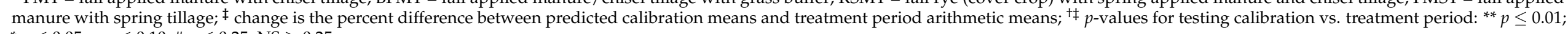
${ }^{*} p \leq 0.05 ;+p \leq 0.10$; $\# \leq \leq 0.25$, NS $\geq 0.25$. 


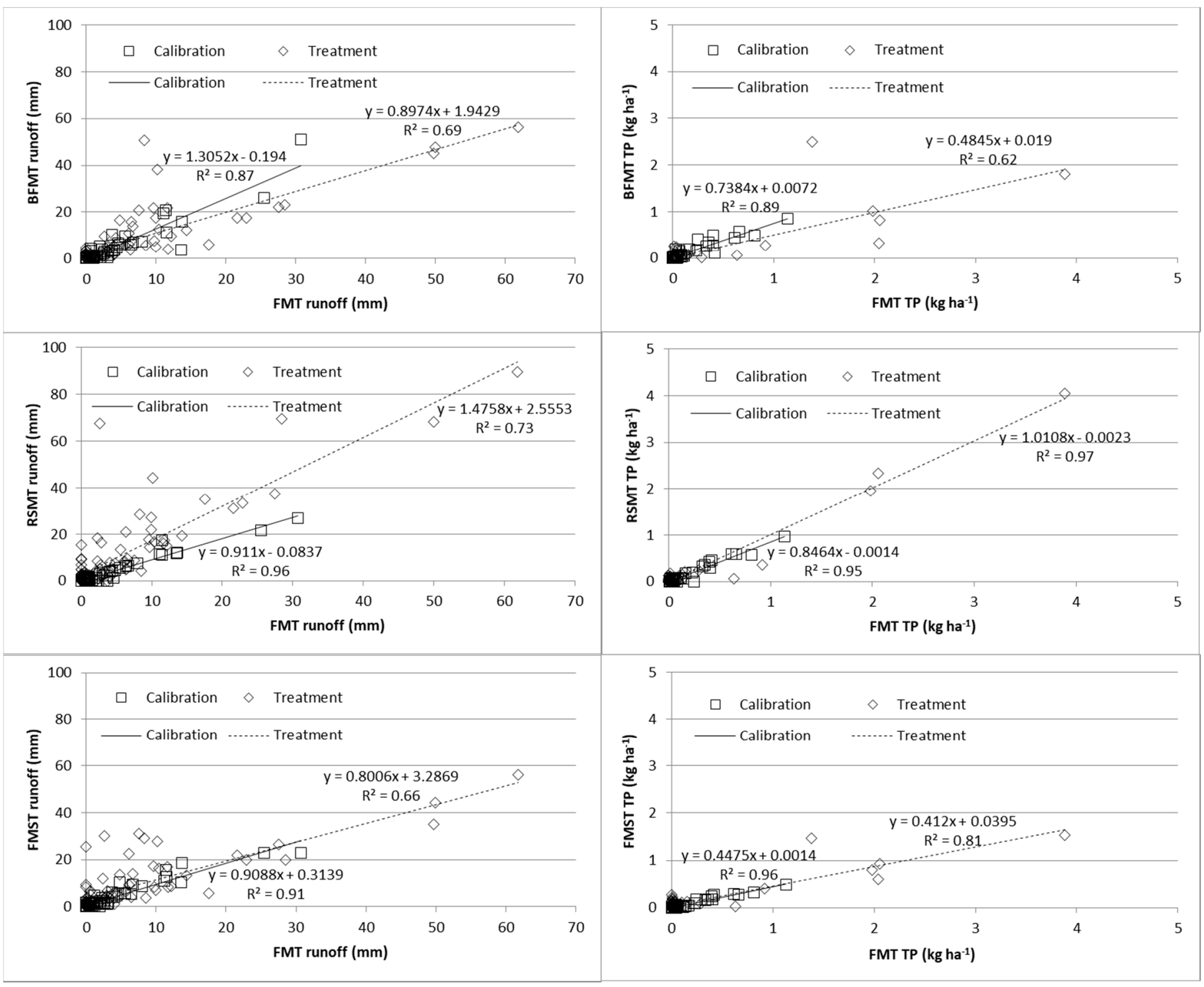

Figure 2. Relationships between each watershed (BFMT = fall applied manure/chisel tillage with grass buffer (top); RSMT = fall rye (cover crop) with spring-applied manure and chisel tillage (center); or FMST = fall applied manure with spring tillage (bottom) and FMT (fall applied manure with chisel tillage) during the calibration and treatment period for runoff quantity $(\mathrm{mm})$ (left) and total P (TP) load $\left(\mathrm{kg} \mathrm{ha}^{-1}\right)$ (right). The solid and dashed lines are linear regressions for the calibration and treatment periods, respectively. 

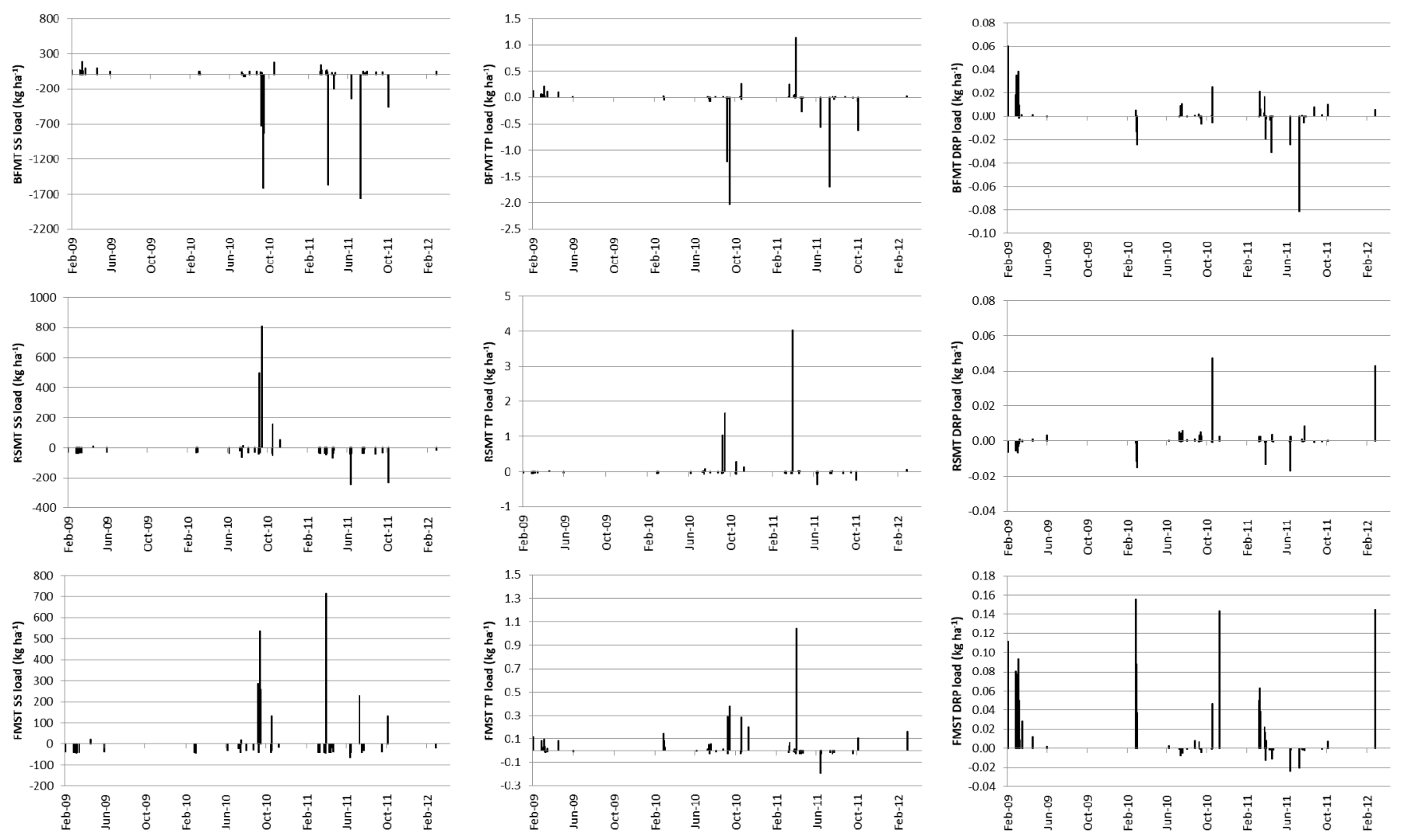

Figure 3. Observed minus predicted values for runoff events throughout the treatment period for each system BFMT = fall applied manure/chisel tillage with grass buffer (top); RSMT = fall rye (cover crop) with spring applied manure and chisel tillage (center); or FMST = fall applied manure with spring tillage (bottom) for suspended solid (SS) load (mg kg-1) (left); total P (TP) load ( $\mathrm{mg} \mathrm{kg}^{-1}$ ) (middle); and dissolved reactive P (DRP) load ( $\mathrm{mg} \mathrm{kg}^{-1}$ ) (right).

The distribution of runoff events in a given hydrologic year is often skewed, with a few large events contributing a majority of the annual runoff, sediment, and/or nutrient loss $[10,66,67]$. We observed a similar phenomenon, with much of the cumulative SS and TP load over the course of the trial coming from a small number of events in early fall after silage harvest when soil is exposed (Figure 1). As a result, the effectiveness of conservation practices may be greatly reduced if they are overwhelmed by one or a few large events.

Much of the annual runoff in cold climate regions is from snowmelt $[11,13,34,35,39,68,69]$. An average of $53 \%$ of annual runoff (averaged across watersheds and control/treatment periods) was derived from snowmelt. We also found greater surface runoff yields during the non-growing season when soils are wetter due to lower evapotranspiration rates. In our study, snowmelt runoff had a much greater proportion of nutrients in dissolved form, for example, $70 \%$ of the TP load for FMST was DRP for snowmelt events as compared to $17 \%$ for rain events. This is consistent with other studies reporting greater DRP/TP ratios for snowmelt compared to rainfall $[13,14,17,39,70,71]$, potentially exacerbating water quality risk due to coincident elevated DRP mobility and high runoff volumes. Runoff DRP and $\mathrm{NH}_{4}{ }^{+}-\mathrm{N}$ loads were generally larger for snowmelt (Table S2) and early spring rainfall events, a loss pattern noted elsewhere $[13,19,69,72,73]$.

Separate analyses of snowmelt and rainfall events showed some differences in relative treatment effects, as indicated by the change between observed and predicted treatment period means (Tables S2 and S3). For rain events, BFMT showed significant decreases in mean runoff concentrations of SS, TP, and all N species (40 to 68\%) and in TP, DRP, and $\mathrm{NH}_{4}{ }^{+}-\mathrm{N}$ loads ( 34 to $84 \%$; Table S3). In contrast, snowmelt events had no significant decreases (some concentrations increased) with significant load decreases only for SS and $\mathrm{NO}_{3}-\mathrm{N}$ (Table S2). While BFMT was much less effective for snowmelt than rain, the $80 \%$ 
reduction in SS load indicates the potential of a vegetative buffer to mitigate particulate $\mathrm{P}$ and SS for snowmelt runoff events [11,13,14,17,19,26,35,67,69]. However, while a vegetated buffer may contribute to a reduction in SS and particulate $P$ transport year-round, buffers are less effective at DRP removal, particularly under conditions of frozen or partially frozen soils [29]. In addition, studies show that snowmelt runoff tends to have a greater proportion of DRP compared to rainfall-induced surface runoff $[26,67]$. In our study, approximately $43 \%$ of TP was in DRP form averaged across watersheds versus $3 \%$ for rain (Tables S2 and S3).

In contrast to BFMT, RSMT had significantly lower mean concentrations of SS and most $\mathrm{P}$ and $\mathrm{N}$ species than predicted in both rain and snowmelt runoff, with somewhat greater reductions in snowmelt. However, because of increased runoff, these were translated into significant decreases in loads only for $\mathrm{SS}, \mathrm{TN}$, and $\mathrm{NO}_{3}-\mathrm{N}$ in snowmelt. Overall, there were only modest treatment effects on $\mathrm{P}$ loads and the other measures for either rainfall or snowmelt events, (although some slopes indicated modest changes), indicating the greatest impact of a rye cover crop occurred outside the growing season, even with minimal rye growth. Spring manure application and tillage minimally impacted nutrient loss likely due to timing, occurring immediately prior to planting, typically during a drier window of time. Only DRP had a slightly (7\%) but significantly greater mean load in the treatment period, most of the higher DRP concentrations found during events occurring post snowmelt but prior to planting (Figure 4).

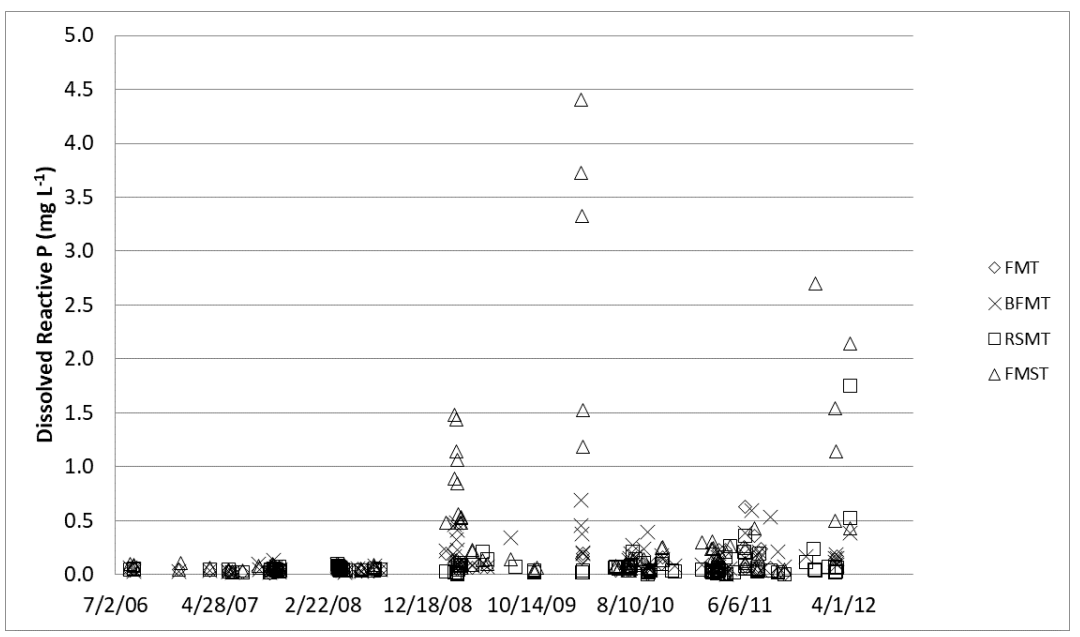

Figure 4. Concentrations $\left(\mathrm{mg} \mathrm{L}^{-1}\right)$ of dissolved reactive $\mathrm{P}(\mathrm{DRP})$ over the study period.

Broadcast application of manure in the fall with tillage delayed until spring (FMST) leaves manure on the soil surface through the non-growing season, resulting in marked water quality contrasts between rain and snowmelt runoff. In rain events, the small (11\%) reduction in SS concentration led to $17 \%$ and $2 \%$ decreases in TN concentration and load, respectively, but no other decreases. There were increases in DRP and $\mathrm{NH}_{4}{ }^{+}-\mathrm{N}$ concentration of about $70 \%$ and loads of 190 and 16\%, respectively. In snowmelt runoff, there were significant decreases in $\mathrm{SS}, \mathrm{TN}$, and $\mathrm{NO}_{3}-\mathrm{N}$ concentrations and $\mathrm{SS}$ and $\mathrm{NO}_{3}-\mathrm{N}$ load. Perhaps the most striking effects were the very large increases in TP, DRP, and $\mathrm{NH}_{4}{ }^{+}-\mathrm{N}(579,647$, and $232 \%$ concentrations, respectively, and 605, 784, and 411\% loads, respectively), emphasizing the runoff water quality risk posed by unincorporated manure left on the soil surface over winter.

\subsection{Research Implications}

Both BFMT and RSMT significantly reduced runoff $\mathrm{SS}, \mathrm{TP}, \mathrm{TN}$, and $\mathrm{NO}_{3}-\mathrm{N}$ concentrations while BFMT also reduced SS, TP, TN, and $\mathrm{NO}_{3}-\mathrm{N}$ loads; however, neither significantly reduced DRP concentration or load. Similar tradeoffs with respect to practices designed to control erosion have been identified in the Lake Erie and other watersheds, where practices 
such as reduced tillage and tile drains can mitigate erosion and TP loss in surface runoff but have the unintended consequence of contributing to elevated runoff DRP risk [74,75]. Encouragingly, RSMT significantly reduced concentrations of SS and all $\mathrm{P}$ and $\mathrm{N}$ species and loads of SS, TN, and $\mathrm{NO}_{3}-\mathrm{N}$ for snowmelt events (Table $\mathrm{S} 2$ ), suggesting a rye cover crop in the fall (with spring tillage) may indeed have potential in corn silage systems to mitigate sediment and P loss in surface runoff. Our results indicate that FMST is not an advisable practice, given its much higher risk of surface runoff DRP loss, as evidenced by the large total and dissolved P load increases (Table 4; Figure 3), especially in snowmelt runoff (on average $605 \%$ and $784 \%$, respectively).

An important result from our study was the relatively large runoff DRP concentrations, especially during the treatment period. Average event runoff DRP concentrations (for all events and/or snowmelt events) were at or above the reported eutrophication threshold of $0.05 \mathrm{mg} \mathrm{L}^{-1}$ (Table 3, Figure 4), indicating runoff would present a freshwater eutrophication risk if discharged directly to streams [76,77]. Overall, DRP increased from about $2.5 \%$ of runoff TP in the calibration period to $12.2 \%$ during the treatment phase. Rye cover crop biomass and/or grass buffer strips may have contributed to increased runoff DRP from those treatments as a result of DRP release from biomass after freeze-thaw events, as previously noted [21,29,61-63]; grass buffer and rye biomass likely altered SS and particulate P transport. However, we hypothesize P from manure and labile soil P forms were more important $\mathrm{P}$ sources to runoff water. Manure can be a direct source of nutrients to runoff, especially when left on the surface (i.e., FMST) where labile $\mathrm{N}$ and $\mathrm{P}$ forms are vulnerable to mobilization in surface runoff. The soluble $\mathrm{NH}_{4}{ }^{+}-\mathrm{N}$ form was about half of total $\mathrm{N}$ in manure (Table 1 ) and may partially explain the large increase, especially for FMST, whereas more variable effects were noted for TN (which includes low soluble organic forms associated with sediment). It is also well established that dairy manure applications increase labile soil $\mathrm{P}$ concentrations as measured by agronomic soil tests [78,79]. Soil samples were taken in 2009 and 2012; mean B1P in fall 2009 was $22 \pm 2 \mathrm{mg} \mathrm{kg}^{-1}$ and increased to $29.5 \pm 1.9 \mathrm{mg} \mathrm{kg}^{-1}$ (37\% increase) by spring 2012 . This $\mathrm{P}$ increase represents a shift from "optimum" to "high" with respect to the University of Wisconsin soil test $\mathrm{P}$ fertility categories [41]. Several studies show that $\mathrm{P}$ release potential to surface runoff increases with greater labile soil P concentrations [80-82]. In WI, B1P is used as an agronomic indicator of plant-available $\mathrm{P}$ and is the basis for determining needed crop $\mathrm{P}$ inputs; it is also an important component in the WI $\mathrm{P}$ index, which is used to determine $\mathrm{P}$ loss risk and develop manure management plans $[17,26,80,83]$. For a range of soil series in WI, Laboski and Lamb [78] showed that both water-soluble P concentrations and the degree of $\mathrm{P}$ saturation increased linearly with B1P, while P sorption strength decreased. It is likely that annual manure applications contributed to the measured B1P increases and runoff DRP concentrations observed in our study. We consider manure $\mathrm{P}$ and soil-bound $\mathrm{P}$ to be the two main sources of runoff $P$ in our study, further highlighting the importance of conservation practices to mitigate both particulate and dissolved $\mathrm{P}$ forms.

The lack of effective control of DRP in runoff was not totally unexpected because the practices evaluated are known to be more effective for erosion and particulate $P$ reduction than dissolved $\mathrm{P}$, suggesting a need for alternative approaches to control dissolved P. One option is the use of injection or other low-disturbance manure application methods, which have been shown to reduce DRP losses substantially compared to surface manure or incorporation by tillage [23,51]. Another is to limit supplementary $\mathrm{P}$ addition to livestock feed, which has resulted in significant reductions in runoff DRP from the application of dairy manure $[18,84,85]$. While our study highlights the importance of controlling erosion and SS transport in order to mitigate P loss, it also demonstrates the inadequacy of the evaluated practices to effectively reduce DRP accumulation in surface soils and the associated greater risk of $P$ transport in surface runoff. Depending on the proximity to open water or other surface water conveyances, our results indicate that additional practices may be needed to mitigate both particulate and dissolved P transport simultaneously and to a degree necessary to protect water quality. 


\section{Conclusions}

Fall manure application and incorporation via chisel plow or other tillage is a common practice on many dairy farms in central WI and other parts of the US. Results from our paired watershed study in central WI indicate that each of the three manure-tillage management systems tested had different potential impacts on surface runoff water quality compared to the control of fall-applied manure with chisel tillage. Both BMPs (BFMT and RSMT) reduced runoff SS, TN, and TP concentrations, but effects on loads were variable, and DRP loads increased slightly. Addition of a vegetative buffer with fall manure application/chisel tillage reduced SS, TP, and total and dissolved $\mathrm{N}$ losses, which made it the most effective BMP. A fall rye cover crop with spring manure application and chisel tillage also shows potential for mitigating sediment, $\mathrm{N}$, and $\mathrm{P}$ transport, but it would be more effective with earlier seeding to achieve more fall growth and ground cover. Ineffective control of DRP losses suggests the need for additional management practices, such as low-disturbance manure application and limiting livestock dietary P. Fall-applied manure with spring tillage incorporation is not recommended due to high runoff $\mathrm{NH}_{4}{ }^{+}-\mathrm{N}$ and DRP losses.

Supplementary Materials: The following are available online at https://www.mdpi.com/2571 $-8789 / 5 / 1 / 1 /$ s1, Table S1: Summary of Abbreviations used, Table S2: Event-based means and regression slopes for calibration and treatment periods, predicted treatment periods means, and hypothesis test results for runoff volume, suspended sediment, and nutrient concentrations and loads for snowmelt events only, Table S3: Event-based means and regression slopes for calibration and treatment periods, predicted treatment periods means, and hypothesis test results for runoff volume, suspended sediment, and nutrient concentrations and loads for rain events only.

Author Contributions: This research project and article were contributed to by the authors in the following way: conceptualization, W.E.J.; methodology, W.E.J.; formal analysis, M.D.C.; investigation, W.E.J.; resources, J.C. and W.K.C.; data curation, J.F.S.; writing-original draft preparation, J.F.S.; writing-review and editing, E.O.Y., W.E.J., and M.D.C.; supervision, W.K.C. All authors have read and agreed to the published version of the manuscript.

Funding: This research was supported in part by the U.S. Department of Agriculture, Agricultural Research Service.

Institutional Review Board Statement: Not applicable.

Informed Consent Statement: Not applicable.

Data Availability Statement: Data is contained within the article or supplementary material. The data presented in this study are available [insert article and supplementary material here].

Acknowledgments: The authors would like to thank Craig Simson, Matt Volenec, and Ashley Braun for excellent technical support in the field and lab and Mike Bertram and the UW MARS staff for equipment operation and assistance with field maintenance. The findings and conclusions in this publication are those of the authors and should not be construed to represent any official USDA or U.S. Government determination or policy.

Conflicts of Interest: The authors declare no conflict of interest.

\section{References}

1. Grande, J.D.; Karthikeyan, K.G.; Miller, P.S.; Powell, J.M. Corn residue level and manure application timing effects on phos-phorus losses in runoff. J. Environ. Qual. 2005, 34, 1620-1631. [CrossRef] [PubMed]

2. Grande, J.D.; Karthikeyan, K.; Miller, P.S.; Powell, J.M. Residue Level and Manure Application Timing Effects on Runoff and Sediment Losses. J. Environ. Qual. 2005, 34, 1337-1346. [CrossRef] [PubMed]

3. Sharpley, A.N.; Chapra, S.C.; Wedepohl, R.; Sims, J.T.; Daniel, T.C.; Reddy, K.R. Managing agricultural phosphorus for pro-tection of surface waters: Issues and options. J. Environ. Qual. 1994, 23, 437-451. [CrossRef]

4. Shipatitalo, M.J.; Edwards, W.M. Runoff and erosion control with conservation tillage and reduced-input practices on cropped watersheds. Soil Till. Res. 1998, 46, 1-12. [CrossRef]

5. Strock, J.S.; Porter, P.M.; Russelle, M.P. Cover Cropping to Reduce Nitrate Loss through Subsurface Drainage in the Northern U.S. Corn Belt. J. Environ. Qual. 2004, 33, 1010-1016. [CrossRef]

6. Thoma, D.P.; Gupta, S.; Strock, J.S.; Moncrief, J.F. Tillage and Nutrient Source Effects on Water Quality and Corn Grain Yield from a Flat Landscape. J. Environ. Qual. 2005, 34, 1102-1111. [CrossRef] 
7. Udawatta, R.P.; Motavalli, P.P.; Garrett, H.E. Phosphorus loss and runoff characteristics in three adjacent agricultural watersheds with clay-pan soils. J. Environ. Qual. 2004, 33, 1709-1719. [CrossRef]

8. Holly, M.A.; Kleinman, P.J.; Bryant, R.B.; Bjorneberg, D.L.; Rotz, C.A.; Baker, J.M.; Boggess, M.V.; Brauer, D.K.; Chintala, R.; Feyereisen, G.W.; et al. Identifying challenges and opportunities for improved nutrient manage-ment through the USDA's Dairy Agroecosystem Working Group. J. Dairy Sci. 2008, 101, 6632-6641. [CrossRef]

9. Bishop, P.L.; Hively, W.D.; Stedinger, J.R.; Rafferty, M.R.; Lojpersberger, J.L.; Bloomfield, J.A. Multivariate Analysis of Paired Watershed Data to Evaluate Agricultural Best Management Practice Effects on Stream Water Phosphorus. J. Environ. Qual. 2005, 34, 1087-1101. [CrossRef]

10. Clausen, J.C.; Jokela, W.E.; Potter, F.I.; Williams, J.W. Paired Watershed Comparison of Tillage Effects on Runoff, Sediment, and Pesticide Losses. J. Environ. Qual. 1996, 25, 1000-1007. [CrossRef]

11. Griffith, K.E.; Young, E.O.; Klaiber, L.B.; Kramer, S.R. Winter Rye Cover Crop Impacts on Runoff Water Quality in a Northern New York (USA) Tile-Drained Maize Agroecosystem. Water Air Soil Pollut. 2020, 231, 84. [CrossRef]

12. Jokela, W.E.; Clausen, J.C.; Meals, D.W.; Sharpley, A.N. Effectiveness of agricultural best management practices in reducing phosphorus loading to Lake Champlain. In Lake Champlain: Partnerships and Research in the New Millennium; Manley, T.O., Manley, P.L., Mihuc, T.B., Eds.; Kluwer Academic Publisher: New York, NY, USA, 2004; pp. 39-52.

13. Liu, J.; Baulch, H.M.; Macrae, M.L.; Wilson, H.F.; Elliott, J.A.; Bergström, L.; Glenn, A.J.; Vadas, P.A. Agricultural Water Quality in Cold Climates: Processes, Drivers, Management Options, and Research Needs. J. Environ. Qual. 2019, 48, 792-802. [CrossRef] [PubMed]

14. Stock, M.N.; Arriaga, F.J.; Vadas, P.A.; Good, L.W.; Casler, M.D.; Karthikeyan, K.G.; Zopp, Z. Fall Tillage Reduced Nutrient Loads from Liquid Manure Application during the Freezing Season. J. Environ. Qual. 2019, 48, 889-898. [CrossRef] [PubMed]

15. Udawatta, R.P.; Garrett, H.E.; Kallenbach, R. Agroforestry Buffers for Nonpoint Source Pollution Reductions from Agricultural Watersheds. J. Environ. Qual. 2011, 40, 800-806. [CrossRef] [PubMed]

16. Uusi-Kämppä, J.; Braskerud, B.; Jansson, H.; Syversen, N.; Uusitalo, R. Buffer Zones and Constructed Wetlands as Filters for Agricultural Phosphorus. J. Environ. Qual. 2000, 29, 151-158. [CrossRef]

17. Vadas, P.A.; Stock, M.N.; Arriaga, F.J.; Good, L.W.; Karthikeyan, K.G.; Zopp, Z.P. Dynamics of Measured and Simulated Dissolved Phosphorus in Runoff from Winter-Applied Dairy Manure. J. Environ. Qual. 2019, 48, 899-906. [CrossRef]

18. Jokela, W.E.; Coblentz, W.K.; Hoffman, P.C. Dairy Heifer Manure Management, Dietary Phosphorus, and Soil Test P Effects on Runoff Phosphorus. J. Environ. Qual. 2012, 41, 1600-1611. [CrossRef]

19. Tiessen, K.H.D.; Elliott, J.A.; Yarotski, J.; Lobb, D.A.; Flaten, D.N.; Glozier, N.E. Conventional and conservation tillage: In-fluence on seasonal runoff, sediment, and nutrient losses in the canadian praries. J. Environ. Qual. 2010, 39, 964-980. [CrossRef]

20. Ulen, B. Nutrient losses by surface run-off from soils with winter cover crops and spring-ploughed soils in the south of Swe-den. Soil Till. Res. 1997, 44, 165-177. [CrossRef]

21. Bechmann, M.; Kleinman, P.J.A.; Sharpley, A.N.; Saporito, L.S. Freeze-Thaw Effects on Phosphorus Loss in Runoff from Manured and Catch-Cropped Soils. J. Environ. Qual. 2005, 34, 2301-2309. [CrossRef]

22. Bundy, L.G.; Andraski, T.W.; Powell, J.M. Management Practice Effects on Phosphorus Losses in Runoff in Corn Production Systems. J. Environ. Qual. 2001, 30, 1822-1828. [CrossRef] [PubMed]

23. Daverede, I.C.; Kravchenko, A.N.; Hoeft, R.G.; Nafziger, E.D.; Bullock, D.G.; Warren, J.J.; Gonzini, L.C. Phosphorus Runoff from Incorporated and Surface-Applied Liquid Swine Manure and Phosphorus Fertilizer. J. Environ. Qual. 2004, 33, 1535-1544. [CrossRef] [PubMed]

24. Sharpley, A.N.; Smith, S. Wheat tillage and water quality in the Southern plains. Soil Tillage Res. 1994, 30, 33-48. [CrossRef]

25. Little, J.L.; Nolan, S.C.; Casson, J.P.; Olson, B.M. Relationships between soil and runoff phosphorus in small Alberta water-sheds. J. Environ. Qual. 2007, 36, 1289-1300. [CrossRef] [PubMed]

26. Vadas, P.A.; Good, L.W.; Jokela, W.E.; Karthikeyan, K.; Arriaga, F.J.; Stock, M. Quantifying the Impact of Seasonal and Short-term Manure Application Decisions on Phosphorus Loss in Surface Runoff. J. Environ. Qual. 2017, 46, 1395-1402. [CrossRef]

27. Feyereisen, G.W.; Wilson, B.N.; Sands, G.; Strock, J.S.; Porter, P.M. Potential for a Rye Cover Crop to Reduce Nitrate Loss in Southwestern Minnesota. Agron. J. 2006, 98, 1416-1426. [CrossRef]

28. Siller, A.R.S.; Albrecht, K.A.; Jokela, W.E. Soil Erosion and Nutrient Runoff in Corn Silage Production with Kura Clover Living Mulch and Winter Rye. Agron. J. 2016, 108, 989-999. [CrossRef]

29. Kieta, K.A.; Owens, P.N.; Lobb, D.A.; Vanrobaeys, J.A.; Flaten, D.N. Phosphorus dynamics in vegetated buffer strips in cold climates: A review. Environ. Rev. 2018, 26, 255-272. [CrossRef]

30. Mayer, P.M.; Reynolds, S.K., Jr.; McCutchen, M.D.; Canfield, T.J. Meta-Analysis of Nitrogen Removal in Riparian Buffers. J. Environ. Qual. 2007, 36, 1172-1180. [CrossRef]

31. Buda, A.R.; Kleinman, P.J.A.; Srinivasan, M.; Bryant, R.B.; Feyereisen, G.W. Effects of Hydrology and Field Management on Phosphorus Transport in Surface Runoff. J. Environ. Qual. 2009, 38, 2273-2284. [CrossRef]

32. Daniels, M.; Sharpley, A.; Harmel, R.; Anderson, K. The utilization of edge-of-field monitoring of agricultural runoff in addressing nonpoint source pollution. J. Soil Water Conserv. 2018, 73, 1-8. [CrossRef]

33. Gburek, W.J.; Sharpley, A.N. Hydrologic Controls on Phosphorus Loss from Upland Agricultural Watersheds. J. Environ. Qual. 1998, 27, 267-277. [CrossRef] 
34. Danz, M.E.; Corsi, S.R.; Brooks, W.R.; Bannerman, R.T. Characterizing response of total suspended solids and total phosphorus loading to weather and watershed characteristics for rainfall and snowmelt events in agricultural watersheds. J. Hydrol. 2013, 507, 249-261. [CrossRef]

35. Good, L.W.; Carvin, R.; Lamba, J.; Fitzpatrick, F.A. Seasonal Variation in Sediment and Phosphorus Yields in Four Wisconsin Agricultural Watersheds. J. Environ. Qual. 2019, 48, 950-958. [CrossRef] [PubMed]

36. Lemke, A.M.; Kirkham, K.G.; Lindenbaum, T.T.; Herbert, M.E.; Tear, T.H.; Perry, W.L.; Herkert, J.R. Evaluating Agricultural Best Management Practices in Tile-Drained Subwatersheds of the Mackinaw River, Illinois. J. Environ. Qual. 2011, 40, 1215-1228. [CrossRef]

37. Clausen, J.C.; Spooner, J. Paired Watershed Study Design; US Environmental Protection Agency, Office of Water: Washington, DC, USA, 1993.

38. Mulla, D.J.; Birr, A.S.; Kitchen, N.R.; David, M.B. Limitations of evaluating the effectiveness of agricultural management practices at reducing nutrient losses to surface waters. In Final Report: Gulf Hypoxia and Local Water Quality Concerns Wrokshop; American Society of Agricultural and Biological Engineers: St. Joseph, MI, USA, 2008; pp. 189-212.

39. Jokela, W.E.; Casler, M. Transport of phosphorus and nitrogen in surface runoff in a corn silage system: Paired watershed methodology and calibration period results. Can. J. Soil Sci. 2011, 91, 479-491. [CrossRef]

40. Peters, J. Recommended Methods of Manure Analysis; University of Wisconsin-Extension, Ed.; University of Wisconsin-Extension: Madison, WI, USA, 2003.

41. Laboski, C.A.M.; Peters, J.B. Nutrient Application Guidelines for Field, Vegetable, and Fruit Crops in Wisconsin; University of Wisconsin-Extension, Cooperative Extension: Madison, WI, USA, 2012.

42. Bray, R.H.; Kurtz, L.T. Determination of total, organic, and available forms of phosphorus in soils. Soil Sci. 2006, 59, 39-46. [CrossRef]

43. Stuntebeck, T.D.; Komiskey, M.J.; Owens, D.W.; Hall, D.W. Methods of Data Collection, Sample Processing, and Data Analysis for Edge-of-Field, Streamgaging, Subsurface-Tile, and Meteorological Stations at Discovery Farms and Pioneer Farm in Wiscon-Sin, 2001-2007; US Geological Survey: Reston, VA, USA, 2008.

44. Brakensiek, D.L.; Osborn, H.B.; Rawls, W.J. (Eds.) Field Manual for Research in Agricultural Hydrology; Agricultural Handbook 224; US Department of Agriculture: Washington, DC, USA, 1979.

45. ASTM International. Standard Test Method for Determining Sediment Concentration in Water Samples; ASTM International, Ed.; ASTM International: West Conshohocken, PA, USA, 2000.

46. APHA. Standard Methods for the Examination of Water and Wastewater, 19th ed.; American Public Health Association, American Water Works Association, and Water Environment Federation: Washington, DC, USA, 1995.

47. Stroup, W.W. Generalized Linear Mixed Models: Modern Concepts, Methods and Applications; CRC Press: Boca Raton, FL, USA, 2012.

48. Good, P. Permutation Tests: A Practical Guide to Resampling Methods for Testing Hypotheses; Springer: New York, NY, USA, 1995; p. 226.

49. Pesarin, F.; Salmaso, L. The permutation testing approach: A review. Statistica 2010, 70, 481-509. [CrossRef]

50. SAS Institute Inc. SAS 9.4 Guide to Software Updates; SAS Institute Inc.: Cary, NC, USA, 2013.

51. Jokela, W.; Sherman, J.; Cavadini, J. Nutrient Runoff Losses from Liquid Dairy Manure Applied with Low-Disturbance Methods. J. Environ. Qual. 2016, 45, 1672-1679. [CrossRef]

52. Sherman, J.F.; Young, E.O.; Coblentz, W.K.; Cavadini, J. Runoff water quality after low-disturbance manure application in an alfalfa-grass hay crop forage system. J. Environ. Qual. 2020, 49, 663-674. [CrossRef]

53. Jokela, W.E.; Grabber, J.H.; Karlen, D.L.; Balser, T.C.; Palmquist, D.E. Cover Crop and Liquid Manure Effects on Soil Quality Indicators in a Corn Silage System. Agron. J. 2009, 101, 727-737. [CrossRef]

54. Karlen, D.L.; Cambardella, C.A.; Kovar, J.L.; Colvin, T.S. Soil quality response to long-term tillage and crop rotation practic-es. Soil Till. Res. 2013, 133, 54-64. [CrossRef]

55. Kaspar, T.C.; Radke, J.K.; Laflen, J.M. Small grain cover crops and wheel traffic effects on infiltration, runoff, and erosion. J. Soil Water Conserv. 2001, 56, 160-164.

56. Eghball, B.; Gilley, J.E. Phosphorus and Nitrogen in Runoff following Beef Cattle Manure or Compost Application. J. Environ. Qual. 1999, 28, 1201-1210. [CrossRef]

57. Yague, M.R.; Andraski, T.W.; Laboski, C.A.M. Manure composition and incorporation effects on phosphorus in runoff fol-lowing corn biomass removal. J. Environ. Qual. 2011, 40, 1963-1971. [CrossRef]

58. Dorioz, J.M.; Wang, D.; Poulenard, J.; Trévisan, D. The effect of grass buffer strips on phosphorus dynamics: A critical re-view and synthesis as a basis for application in agricultural landscapes in France. Agric. Ecosyst. Environ. 2006, 117, 4-21. [CrossRef]

59. Roberts, W.M.; Stutter, M.I.; Haygarth, P.M. Phosphorus Retention and Remobilization in Vegetated Buffer Strips: A Review. J. Environ. Qual. 2012, 41, 389-399. [CrossRef]

60. Udawatta, R.P.; Krstansky, J.J.; Henderson, G.S.; Garrett, H.E. Agroforestry practices, runoff, and nutrient loss: A paired watershed comparison. J. Environ. Qual. 2002, 31, 1214-1225. [CrossRef]

61. Aronsson, H.; Hansen, E.M.; Thomsen, I.K.; Liu, J.; Ogaard, A.F.; Känkänen, H.; Ulén, B. The ability of cover crops to reduce nitrogen and phosphorus losses from arable land in southern Scandinavia and Finland. J. Soil Water Conserv. 2016, 71, 41-55. [CrossRef] 
62. Roberson, T.; Bundy, L.G.; Andraski, T.W. Freezing and Drying Effects on Potential Plant Contributions to Phosphorus in Runoff. J. Environ. Qual. 2007, 36, 532-539. [CrossRef]

63. Wendt, R.C.; Corey, R.B. Phosphorus Variations in Surface Runoff from Agricultural Lands as a Function of Land Use. J. Environ. Qual. 1980, 9, 130-136. [CrossRef]

64. Maguire, R.O.; Kleinman, P.J.A.; Dell, C.J.; Beegle, D.B.; Brandt, R.C.; McGrath, J.M.; Ketterings, Q.M. Manure Application Technology in Reduced Tillage and Forage Systems: A Review. J. Environ. Qual. 2011, 40, 292-301. [CrossRef] [PubMed]

65. Sherman, J.F.; Young, E.O.; Jokela, W.E.; Cavadini, J. Influence of low-disturbance fall liquid dairy manure application on corn silage yield, soil nitrate, and rye cover crop growth. J. Environ. Qual. 2020, 49, 1298-1309. [CrossRef] [PubMed]

66. Coelho, B.B.; Murray, R.; Lapen, D.; Topp, E.; Bruin, A.J. Phosphorus and sediment loading to surface waters from liquid swine manure application under different drainage and tillage practices. Agric. Water Manag. 2012, 104, 51-61. [CrossRef]

67. Klaiber, L.B.; Kramer, S.R.; Young, E.O. Impacts of Tile Drainage on Phosphorus Losses from Edge-of-Field Plots in the Lake Champlain Basin of New York. Water 2020, 12, 328. [CrossRef]

68. Hoffman, A.; Polebitski, A.S.; Penn, M.R.; Busch, D.L. Long-term Variation in Agricultural Edge-of-Field Phosphorus Transport during Snowmelt, Rain, and Mixed Runoff Events. J. Environ. Qual. 2019, 48, 931-940. [CrossRef]

69. Liu, J.; Macrae, M.L.; Elliott, J.A.; Baulch, H.M.; Wilson, H.F.; Kleinman, P.J. Impacts of Cover Crops and Crop Residues on Phosphorus Losses in Cold Climates: A Review. J. Environ. Qual. 2019, 48, 850-868. [CrossRef]

70. Ginting, D.; Moncrief, J.F.; Gupta, S.C.; Evans, S.D. Interaction between Manure and Tillage System on Phosphorus Uptake and Runoff Losses. J. Environ. Qual. 1998, 27, 1403-1410. [CrossRef]

71. Ulén, B. Concentrations and transport of different forms of phosphorus during snowmelt runoff from an illite clay soil. Hydrol. Process. 2002, 17, 747-758. [CrossRef]

72. Hansen, N.C.; Daniel, T.C.; Sharpley, A.N.; Lemunyon, J.L. The fate and transport of phosphorus in agricultural Systems. J. Soil Water Conserv. 2002, 57, 408-417.

73. Glozier, N.E.; Elliott, J.A.; Holliday, B.; Yarotski, J.; Harker, B. Water Quality Characteristics and Trends in a Small Agricultural Watershed: South Tobacco Creek, Manitoba, 1992-2001; Environment Canada: Saskatoon, SK, Canada, 2006.

74. Jarvie, H.P.; Johnson, L.T.; Sharpley, A.N.; Smith, D.R.; Baker, D.B.; Bruulsema, T.W.; Confesor, R. Increased Soluble Phosphorus Loads to Lake Erie: Unintended Consequences of Conservation Practices? J. Environ. Qual. 2017, 46, 123-132. [CrossRef]

75. Smith, D.R.; King, K.W.; Johnson, L.R.; Francesconi, W.; Richards, P.; Baker, D.; Sharpley, A.N. Surface Runoff and Tile Drainage Transport of Phosphorus in the Midwestern United States. J. Environ. Qual. 2015, 44, 495-502. [CrossRef] [PubMed]

76. Carpenter, S.R.; Caraco, N.F.; Correll, D.L.; Howarth, R.W.; Sharpley, A.N.; Smith, V.H. Nonpoint Pollution of surface waters with phosphorus and nitrogen. Ecol. Appl. 1998, 8, 559-568. [CrossRef]

77. Sharpley, A.N.; Troeger, W.W.; Smith, S.J. The Measurement of Bioavailable Phosphorus in Agricultural Runoff. J. Environ. Qual. 1991, 20, 235-238. [CrossRef]

78. Laboski, C.A.M.; Lamb, J.A. Changes in soil test phosphorus concentration after application of manure or fertilizer. Soil Sci. Soc. Am. J. 2003, 67, 544-554. [CrossRef]

79. Sharpley, A.; McDowell, R.W.; Kleinman, P.J.A. Amounts, Forms, and Solubility of Phosphorus in Soils Receiving Manure. Soil Sci. Soc. Am. J. 2004, 68, 2048-2057. [CrossRef]

80. Good, L.W.; Vadas, P.; Panuska, J.C.; Bonilla, C.A.; Jokela, W.E. Testing the Wisconsin Phosphorus Index with Year-Round, Field-Scale Runoff Monitoring. J. Environ. Qual. 2012, 41, 1730-1740. [CrossRef]

81. Magdoff, F.; Hryshko, C.; Jokela, W.E.; Durieux, R.P.; Bu, Y. Comparison of Phosphorus Soil Test Extractants for Plant Availability and Environmental Assessment. Soil Sci. Soc. Am. J. 1999, 63, 999-1006. [CrossRef]

82. Vadas, P.A.; Kleinman, P.J.A.; Sharpley, A.N.; Turner, B.L. Relating Soil Phosphorus to Dissolved Phosphorus in Runoff: A Single Extraction Coefficient for Water Quality Modeling. J. Environ. Qual. 2005, 34, 572-580. [CrossRef]

83. Andraski, T.W.; Bundy, L.G. Relationship between phosphorus levels in soil and in runoff from corn production systems. J. Environ. Qual. 2003, 32, 310-316. [CrossRef]

84. Ebeling, A.M.; Bundy, L.G.; Powell, J.M.; Andraski, T.W. Dairy Diet Phosphorus Effects on Phosphorus Losses in Runoff from Land-Applied Manure. Soil Sci. Soc. Am. J. 2002, 66, 284-291. [CrossRef]

85. Hanrahan, L.P.; Jokela, W.E.; Knapp, J.R. Dairy Diet Phosphorus and Rainfall Timing Effects on Runoff Phosphorus from Land-Applied Manure. J. Environ. Qual. 2009, 38, 212-217. [CrossRef] [PubMed] 